\title{
FIGURATIVE MEANING IN ALANI HAPOGOSAN MOVIE
}

\author{
*Wantika Br Dabutar \\ ** Sumarsih
}

\begin{abstract}
This study deals with the Figurative Meaning in Alani Hapogosan Movie. The objectives of the study are to describe the types of figurative language used in Alani Hapogosan Movie, the dominant type of the figurative language and the cultural values of the movie itself. This study was conducted by descriptive qualitative method. The data were collected from the Alani Hapogosan by transcribing them. In analyzing the data, there are 4 types of figurative language were used. The most dominant used is Metaphor $25(44,64 \%)$, the second is Idioms $18(32,14 \%)$, the third is Proverbs $11(19,64 \%)$, the last is Metonymy 2 $(3,57 \%)$ and there was not Irony occured in Alani Hapogosan movie. There were 8 cultural values that occured in the movie: Kinship (Kekerabatan), Religion (Religi), Wealth (Hamoraon), Honor (Hasangapon), Progress (Hamajuon), Law (Hukum), Guardianship (Pangayoman), Conflict (Konflik). And there was a cultural values that didn't occur in Alani Hapogosan movie. It is Have Many Children (Hagabeon).
\end{abstract}

Keyword : Figurative Meaning, Movie 


\section{Introduction}

Language is an inseparable part of human life to express thought, feelings, desires and intention both in spoken and written way. Spoken is the process of expressing ideas and feelings or giving information orally, song, speech and conversation. Written is done in writing activity, available in short story, article, novel, newspaper, poetry, letter, magazine, song lyric and etc. The word meaning is commonly found in spoken and written language.

People can use language literally and figuratively. Literally means the meaning of the language that is used based on dictionary or usually called grammatical. Figuratively means a way of saying other than the literal meaning of the words or usually called figure of speech. People may find it difficult to interpret whether the language has literal or figurative meaning.

Figurative meaning is language that uses words or expression with a meaning that is different from literal interpretation, when a researcher uses literal language, he or she simply stating the facts as they are. Figurative meaning is meaning out of the real meaning or imaginative that encourages our imagination. The meaning of the words is influenced by the words which exist around it in sentence. Because the figurative meaning shows the beauty of the language, some of the writer, poet, motivator, movie maker use figurative language to express their thinking and their feeling into a language. Beside that people prefer using language figuratively in order to make their language more beautiful, and stylish. It can help the listeners or the readers feel the language deeply and are touched by it.

Figurative language is understood through comprehending the literal meaning of a word or a phrase in a sentence, and then it is connected to the context where the figurative language takes place in 
order to know what hidden meaning and message that a researcher or speaker wants to convey.

Figurative meaning is an interesting study to studied and analyzed. It is used to beautify and refine the language. Some figuratives expression also contained in those movie requires a deep analysis. Each utterances convey different meaning. To understand about figurative language and to see the application of figurative meaning has been the choice for many movie makers in making their movie.

Alani Hapogosan movie is Bataknese movie which tells about a poor man's life, and his struggle to reach his dream. The movie use Bataknese language and use many figurative language. The movie applies many figurative meaning for some purpose that has encouraged the researcher to do the research to see the characteristics of each style in figurative meaning that was applied in the movie. In this movie we can find many types of figurative meaning.

All the figures of speech will be explained. The figure of speech can be a device to maintain Toba Batak's culture. The researcher also hopes that the finding of this study will give many contribution to all people to be proud about their culture and introduce Toba Batak language deeply.

\section{Theoritical Review}

\section{Semantics}

Semantics is one of linguistics branches, which studied about language meaning. Griffiths (2006:1) states that semantics is the study of the toolkit for meaning, knowledge encoded in the vocabulary of the language and in its patterns for building more elaborate meanings, up to the level of sentence meanings. Saeed (1997:3) stated that semantics is the study of meaning communicated through language. 


\section{Literal Meaning}

According to Saeed (1997: 8) literal meaning is a context- free element of meaning, isolate the meaning of word from any possible context. Cruse (2006 : 96) states that the term literal usually applies to one of the current meanings of a polysemous word.

\section{Figurative Meaning}

Figurative meaning is language that can not be taken literally. In the other words, a mode of expression in which words are used out of their literal meaning or out of their ordinary use in order too add beauty or emotional intensity.

\section{Kinds of Figurative Meaning}

Figurative meaning is a way of saying something other than an ordinary way. Figurative meaning can be divided into five namely metaphor, metonymy, idioms, proverbs and irony (Gibbs and Herbert : 2012)

\section{Metaphor}

Metaphor is a figure of speech in which a name of descriptive word or phrase is transferred to an object or action in different form, but analogous to, that which it is literally applicable. Metaphors are a way to describe two objects without using the words "like" or "as".

Examples : Library is the store of knowledge ( Library is the source of knowledge )

\section{Metonymy}

Metonymy is a figure of speech in which one thing is used to stand for itself, brand, cause and effect.

Examples : My mother always drink Kapal Api every morning (Kapal Api means coffee)

\section{Irony}


Irony is a figure of speech when an expression used in the opposite of the thought in speaker's mind, this conveying a meaning that contradicts the literal defenition.

Example : You are a brilliant student who does not have knowledge ( lacking intelligence)

\section{Idioms}

Kreuz et al.'s in Gibbs (2012 : 50) stated that idiom is segments that contain special meanings not obtainable from the usual meaning of the words in an expression. Example : He kick the bucket (Die)

\section{Proverbs}

A proverb is a simple and concrete saying, popularly known and repeated, that expresses a truth based on common sense or experience. Example : Ignorance is bliss ( ketidaktahuan adalah kebahagiaan )

\section{Cultural Values of Toba Batak}

Kinship, religion, hagabeon, hasangapon, hamoraon, hamajuon, law, guardianship and conflict are cultural values of Batak Toba and becoming their life principle of their society (Harahap and Siahaan 1987 : 134) .

\section{Kinship (Kekerabatan)}

Which includes the relationship premordial interest, affection on the based of blood relationship, harmony Dalihan Na Tolu (Hula- hula, Dongan Tubu, Boru), Bonana Raut (Son of son of Boru, Hatobangan (Scholars) and everything related links kinship by marriage, clan solidarity and others.

\section{Religion (Religi)}

Includes religious life, both traditional religion and religion that come later that manage its relationship with the Creator and its relationship with humans and their environment. 


\section{Wealth (Hamoraon)}

Rich, one of the underlying cultural values and encourage the Batak people, especially the Toba, to find a lot of property. And old Batak says "Anak do hamoraon" means lots of children, lots of luck.

\section{Have Many Children (Hagabeon )}

Many of spring and longevity traditional of the famous Batak presented during the wedding ceremony is an expression that expects to be given later newlywed son 17 and daughter 16. Human resources for the Batak people is very important.

\section{Honor (Hasangapon)}

Glory, authority, charisma, a core value that gave a strong status to achieve greatness. This value gives a strong impetus, especially in Toba Batak society, in this modern era to reach the position and rank that gives glory, authority, charisma and power.

\section{Progress (Hamajuon)}

A cultural value include the progress that reach by wander and looking for knowledge. This cultural value motivate the Batak society to immigrate to all places in this world.

\section{Law (Hukum)}

Another cultural value is the patik or law. The law value is the strongest value in Batak society. This value is born from the frequency of the violation of role of lawn in Batak's life.

\section{Guardianship (Pangayoman)}

A cultural value in the socio- cultural life is not strong than the values that mentioned in the previous, it is because of the independence. 
The presence of guardianship, protector, and the welfare giver just needed in urgent time.

\section{Conflict (Konflik)}

A cultural values of Batak society that talking about the Batak daily life that connected to the problem of Batak. Generally the conflict is appear when there is something force a group to fight.

\section{Methodology and Discussion}

In conducting this research, the writer use descriptive qualitative research to find out figurative meaning in Alani Hapogosan movie. The source of the data was taken from "Alani Hapogosan" movie part 1 and 2.

\section{Types of Figurative Language}

\section{Metaphor}

In the figurative language known a metaphor, two or more objects or ideas are linked together without the use of words as "like" or "as". Amani Lesta :Boha ma baenonhu da bere. Dang na so hupikkiri hamu alai nga dibege ho sude. Na husari nantulangmu do maniop i sude. Jala mo nga sahat tu tanganna lomo na ma mangatur. Dang tarhutip be i. Ale, unang ho mabiar da. Nantulang mi songon narnar ni api do $i$, mago do i molo disiram dohot aek.

From the conversation above, the phrase narnar ni api do $\boldsymbol{i}$, mago do i molo disiram dohot aek (Your aunty is a temperamental women who will changed with goodness) shows us that the sentence are metaphor. It is not important to use connective such as like or as. 


\section{Idiom}

The term idiom is usually applied to multi-word phrases, although theoretically words consisting of more than one morpheme can exhibit similar properties.

Nai Sondang : Eda nai Sahat.! Ai gogo hian ho karejo, hape umurmu nga uttua sian au. Hehehe

Nai Sahat : Ba boha ma baenon da eda. Ngolu on ikkon do mardalan. Dibereng edakku do haru holan passikkolahon beremu si Sahat pe sian SMP nga disudahon hau tanggurung dibola dohot gotting. Pahundul majo hita dison, unang majo pittor mulak hamu. Makata-hatai majo hita. Nga tung leleng dang hea ro Eda mandulo hami tu lopo-lopo on. Boha do anggiku si Sondang? Tu dia do imana marsikkola muse ?

From the conversation above the sentence nga disudahon hau tanggurung dibola dohot gotting (All has been sacrified) shows us that the sentence is an Idiom. It can be seen in the meaning of the phrase can not be derived from the first sentence.

\section{Proverbs}

A proverb is a simple and concrete saying, popularly known and repeated, proverbs are borrowed from similar language and cultures.

Nai Sondang : Ai burju hian do hubereng si Sahat mon eda. Aut jolma na lobian au urupanku do parsikolahon ibana.

Nai Sahat :Sipata da edakku dang sude nadi rohattai dituppaki Tuhani.Ndanda simanuk- manuk sibottar andora. Ndada sitolu turpuk siahut loma ni roha. Martangiang do nean au anggiat boi anggiku si Sondang marsikkola. 
From the conversation above the sentence Ndanda simanukmanuk sibottar andora. Ndada sitolu turpuk siahut loma ni roha (Everything is depends on God not our will.) shows us that the sentence is Proverb. The sentence is a common cultural sentence that acquire by Bataknese people.

\section{Irony}

Irony is a figure of speech when an expression used in the opposite of the thought in speaker's mind, this conveying a meaning that contradicts the literal defenition. In this movie the writer can not find the sentences that use irony.

\section{Metonymy}

Metonymy is the substitution of an attribute for the name of a person or thing; the whole stands for the part.

Nai Sahat :I ma na naeng borhat ho amang sian hutatta on tu pangarattoan lao manuhori perbinotoan pinitta ni sipanganon on songon goar na i ma asa Amatta Debata ma na mangaturhon ngolum. Asa lam marungaran nean goar ni Oppungmu dohot amongmu na hinan. Alani ni akka pasu- pasu tu ho tu joloan on. Jala songon dai nai ma tabo ni ari - ari sidalananmu jala tabo ni baritam begeon ni hami sude keluargam, tarlobi ma au inong mon. Sotung lupa ho amang tu hami, unang gabe si Mardan ho amang. Pangan maho amang, las ma roham dohot tondim. Buat ma amang, allang ma na dilomo no roham.

Sahat :Olo Inong.

From the conversation above the sentence unang gabe si Mardan ho amang (Never forget your family at hometown like Mardan) shows us that the sentence is metonymy. Mardan is an image of a person that forget his hometown and his family. 
The Occurences of Figurative Language in Alani Hapogosan Movie

\begin{tabular}{|c|c|c|c|}
\hline No & Types of Figurative Language & Frequency & Percentage \\
\hline 1 & Metaphor & 25 & $44,64 \%$ \\
\hline 2 & Idioms & 18 & $32,14 \%$ \\
\hline 3 & Proverbs & 11 & $19,64 \%$ \\
\hline 4 & Irony & 0 & $0 \%$ \\
\hline 5 & Metonyny & 2 & $3,57 \%$ \\
\hline & Total & 56 & $100 \%$ \\
\hline
\end{tabular}

\section{Cultural Values of the Movie}

The way how figure of speech reflected Toba Batak culture is by identifying the figure of speech reflected Toba Batak culture namely :

\section{Kinship (Kekerabatan)}

In relationship premordial interest, affection on the basis of blood relationships can be seen in te movie. "Jala ho pe Inang ni Lesta, adong do hata ni natua- tua Amak do rere, anak do bere Jadi ta etong ma si Sahat on songon anak na tubu sian siubeonta", which mean berel anak na tubu sian siubeonta showes their solidarity and the kinship in Toba Batak culture. Bere is the name name for nephew in Batak and Bere also called as real daughter/son.

\section{Religion (Religi)}

Toba Batak society had an intimate realtionship with their Creator. They always rely everything it could be seen from the sentence 'sada na so boi lupahononmu ima martangiang jala ikkon tongtong lao tu gareja. Sahali pe sotung hea ditinggalhon ho da amang. Ingot da amang biar mida Jahowa do mula ni hapistaran. Alai halak na oto manoisi 
hapistaran dohot pangajaran' which meant God must be the first person in their life. They must rely their life to God and never leave the God. Fear of God is the beginning of the knowledge.

\section{Wealth (Hamoraon)}

Figure of speech categorized as hamoraon value in can be seen from the sentence "Pos do rohakku tu ho da anakku, hasiankuu, tappuk ni pusu- pusukku" which meant that a son is everything for the parents. Son/daughter is the most valuable treasure for Toba Batak people.

\section{Have Many Children (Hagabeon)}

An old Batak said "Anak do hamoraon" meaning "lots of children lots of luck". But in this movie we can not find the figure of speech that reflect hagabeon.

\section{Honor (Hasangapon)}

Glory, authority, charisma, a core value that gave a strong status to achieve greatness. This value give a strong impetus especially in Toba People, in this modern era to reach the position and rank that gives glory, authority, charisma and power. Nai Lesta, argaanmu do sipata nean au songon uluan di jabu on. This sentence is the wish of a man to be predicated as the leader in a family.

\section{Progress (Hamajuon)}

A cultural value include the progress that reach by wander and looking for knowledge. Ima na naeng borhat ho amang sian hutatta on tu pangarattoan lao manuhori perbinotoan. This sentence means that knowledge is the important thing for Toba Batak people. Knowledge is a primary needs for life. 


\section{Law (Hukum)}

Another cultural value is the patik or law. The law value is the strongest value in Batak society. Na so jadi oloanmu manang pangalaho akka na babiat i. Ikkon burju ho marsiajar di jabu ni tulangmu. Berengma parngoluantta on, molo pat dang mangois, baba dang mangan. This sentence means that if we do not work we can not eat. It is the implicit meaning that everybody have to work to fulfill their life.

\section{Guardianship (Pangayoman)}

The presence of guardianship, protector, and the welfare giver just needed in urgent time. "Amangboru, urupi majo au. Amangboruu! Si Sahat donganhu sian huta i nga ditakkup geng ni si Raden.Amangboru urupi majo au! Sahalion pe." In this movie the guardianship values seen in when Ingot try to save Sahat he ask for the guarrdianship to his last Boss. It is the condition that really urgent.

\section{Conflict (Konflik)}

A cultural values of Batak society that talking about the Batak daily life that connected to the problem of Batak. Generally the conflict is appear when there is something force a group to fight. "Dang sarupa hami dohot ho. Tikki marhepeng ho langit i pe angir do dianggo ho nuaeng dung surpuk ho songon on ro ma ho tu hami" This is one of the conflict that appear in the movie.

\section{Conclusion}

There are four types of figurative language that are used in Alani Hapogosan Movie. They are Metaphor, Idiom, Metonymy, and Proverbs. And the dominant types of figurative language that used is Metaphor. Metaphor tent to give cultural meaning with comparing characteristics, behaviors of vegetation or objects what were around humans. There are 8 types of cultural values that are used in Alani Hapogosan movie. While 
there is a types of cultural values that is not used in Alani Hapogosan movie, it is have many children (Hagabeon).

\section{References}

Alcott, Louisa May. 2012. Analysis English Figurative Language in Novel Little Me by Arsyani. Journal of Tanjungpura University.

Cruse, Alan D. 2000. Meaning in Language. United States : Oxford University Press

— 2006. A Glossary of Semantics and Pragmatics. Edinburgh : Edinburgh University Presss

Gibbs, Colston . 2012. Interpreting Figurative Meaning. United States of America : Cambridge University Press

Griffiths, Pattrick. 2006. An Introduction to English Semantics and Pragmatics. Edinburgh : Edinburgh University Press.

Harahap, Basyral Hamidy dan Siahaan, Hotman. 1987. Orientasi Nilai Nilai Budaya Batak. Jakarta : Sanggar Willem Iskandar

Hutajulu, Ruth Stevy. 2012. Figurative Language in Mata Najwa Talk Show's notes. Unpublished Thesis. Universitas Negeri Medan

Keraf, Gorys. 1996. Diksi dan Ragam Bahasa. Jakarta : Gramedia Pustaka

Lestari, Ayu Septia. 2015. Figurative Language in The Old and New Minang Pop Songs. Unpublished Thesis. Universitas Negeri Medan

Moleong, L.J.2000. Metodologi Penelitian Kualitatif .Bandung : P.T. Remaja Rosdakarya

Retnayanthi, Putu Ayu. 2012. The Analysis of Figurative Language in Adele's Song Lyrics. Jurnal Universitas Udayana

Riemer, Nick. 2010. Introducing Semantics. New York : Cambridge University Press 
Rosyida, Kholifah. 2011. The Using of Figurative Language in Confession of A Shopaholic Movie. Salatiga : State Institute for Islamic students (STAIN)

Saeed, Jhon, I. 1997. Semantic. China : Blackwell Publisher

Simamora, Cahaya Lisdawati. 2014. Figurative Meaning in Adele's song Lyrics.

Simanjuntak, Hotnida.2013. Cultural Values in Umpasa and Uses in Traditional Marriage Ceremony District Lingtongnihuta Batak Toba Humbang Hasundutan. State University of Medan.

Siti Nur, Rohmah.(2012). An Analysis Of Figurative Language used in Gola Gong's Novel "Bila Waktu Bicara" 